\title{
Ochronotic Spondyloarthropathy Mimicking Diffuse idiopathic Skeletal Hyperostosis
}

Sadettin Uslu, M.D.

Department of Rheumatology, Ömer Halisdemir University Bor Physical Medicine and Rehabilitation, Training and Research Hospital, Niğde, Turkey

\section{INTRODUCTION}

A 59-year-old man presented with 20 years history of low back pain. The pain was mechanical in nature with early morning stiffness of less than 15 minutes. The patient was followed-up with a diagnosis of diffuse idiopathic skeletal hyperostosis (DISH) by the other physicians. He had partial response to analgesics.

On inquiry, the patient reported that since childhood his urine had turned a dark color on exposure to air. Physical examination revealed blue-black pigmentation of the sclera and ear pinna bilaterally (Figure 1). On laboratory, full blood count, calcium, phosphorus, alkaline phosphatase, erythrocyte sedimentation rate, C-reactive protein and rheumatoid factor were normal. HLA B-27 was also negative. Measurement of 24 hours urinary homogentisic acid levels was $957 \mu \mathrm{mol} / \mathrm{mmol}$ creatinine (reference value, $<1 \mu \mathrm{mol} / \mathrm{mmol}$ creatinine). X-ray showed multilevel intervertebral disc space narrowing associated with disc calcifications of the thoracolumbar spine (Figure 1). The diagnosis of ochronosis was established, ascorbic acid and nitisinone were started for the patient. Protein restriction was made in his diet.

Ochronosis is a rare hereditary autosomal recessive disorder characterized by an excess of homogentisic acid deposits in the tissues. The incidence of ochronosis (alkaptonuria) is estimated at 1 case in 250,000 to 1 million live births [1]. Ochronotic arthropathy generally appears in the third decade, commonly affects in which weight bearing joints and the thoracolumbar spine. Narrowing of the intervertebral spaces and widespread, thin, linear, wafer-like disc calcification are diagnostic findings seen on spine radiographs [2]. A potential agent called $2 \mathrm{mg}$ of daily nitisinone has been shown to decrease clinical progression of ochronosis [3]. Disc calcifications
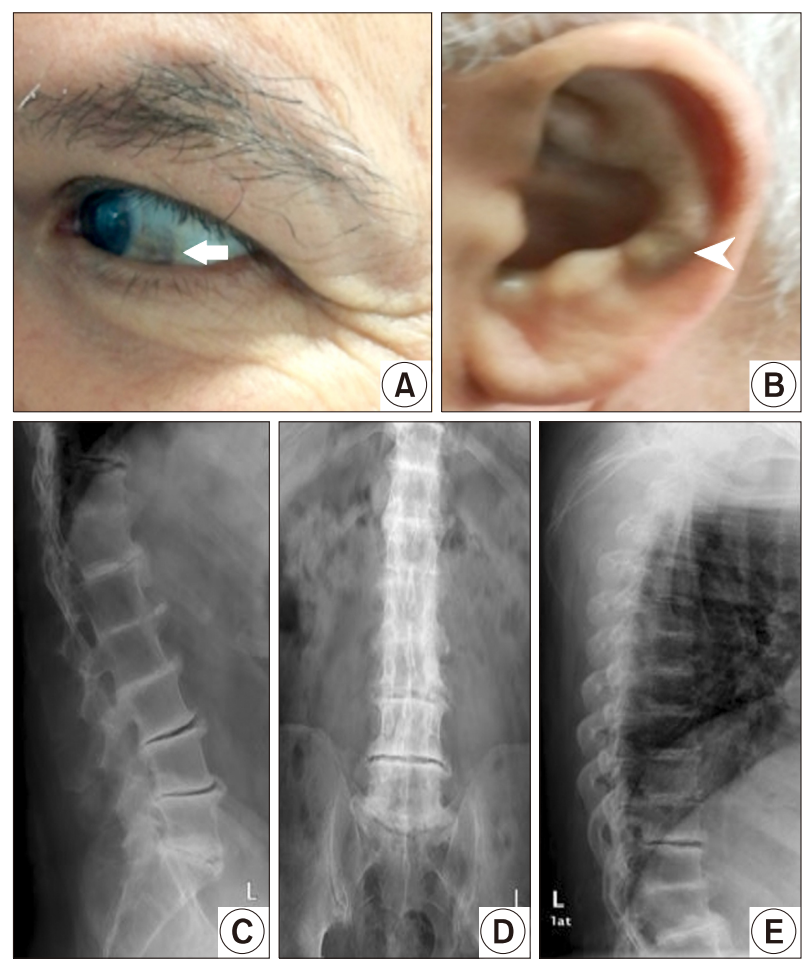

Figure 1. Photographs show blue-black pigmentation of the sclera (arrow) (A) and ear pinna (arrowhead) (B), X-ray of the thoracolumbar spine, multilevel intervertebral disc space narrowing associated with disc calcifications $(C \sim E)$. We received the patient's consent form about publishing all photographic materials.

Received : May 20, 2020, Revised : May 21, 2020, Accepted : May 22, 2020

Corresponding to : Sadettin Uslu iD http://orcid.org/0000-0001-6266-2454

Department of Rheumatology, Ömer Halisdemir University Bor Physical Medicine and Rehabilitation, Training and Research Hospital, Dr. Doğan Baran Avenue on Okçu Road 1.km Bor, Niğde 51200, Turkey. E-mail : sadouslu@gmail.com

Copyright (c) 2020 by The Korean College of Rheumatology.

This is an Open Access article, which permits unrestricted non-commerical use, distribution, and reproduction in any medium, provided the original work is properly cited. 
must be distinguished from those of the following: ankylosing spondylitis, juvenile idiopathic arthritis, DISH, calcium pyrophosphate dehydrate crystal deposition disease, hyperparathyroidism, Klippel-Feil syndrome, and congenital and acquired fusions of the spine [4]. The diagnosis of ochronosis must be considered for any patient with multilevel vertebral-body disc involvement.

\section{CONFLICT OF INTEREST}

No potential conflict of interest relevant to this article was reported.

\section{REFERENCES}

1. Phornphutkul C, Introne WJ, Perry MB, Bernardini I, Murphey MD, Fitzpatrick DL, et al. Natural history of alkaptonuria. N Engl J Med 2002;347:2111-21.

2. Ventura-Ríos L, Hernández-Díaz C, Gutiérrez-Pérez L, Bernal-González A, Pichardo-Bahena R, Cedeño-Garcidueñas $\mathrm{AL}$, et al. Ochronotic arthropathy as a paradigm of metabolically induced degenerative joint disease. A case-based review. Clin Rheumatol 2016;35:1389-95.

3. Ranganath LR, Khedr M, Milan AM, Davison AS, Hughes AT, Usher JL, et al. Nitisinone arrests ochronosis and decreases rate of progression of Alkaptonuria: evaluation of the effect of nitisinone in the United Kingdom National Alkaptonuria Centre. Mol Genet Metab 2018;125:127-34.

4. Toth K, Lenart E, Janositz G, Takacs K. Ochronotic arthropathy. Scand J Rheumatol 2003;32:315-7. 